\title{
Michael Drayton
}

1563-1631

Michael Drayton was born in Warwickshire, the son of a tanner. $\mathrm{He}$ received his education while serving as a page in the household of Sir Henry Goodere, a local squire who had been a friend of Sir Philip Sidney. He fell in love with Sir Henry's daughter, Anne Goodere, and remained devoted to her after she married; she is the 'Idea' whom Drayton celebrated in his sonnets. Drayton became a prolific poet, favouring long poems on historical subjects. His largest project was Poly-Olbion, a vast poem which describes the topography of England. His famous ode 'To the Virginian Voyage' celebrates the voyage of the Sarah Constant, the Godspeed and the Discovery to Virginia in December 1606.

\section{TO THE VIRGINIAN VOYAGE}

You brave heroic minds,

Worthy your country's name,

That honour still pursue,

Go, and subdue,

5 Whilst loitering hinds ${ }^{\dagger}$

Lurk here at home, with shame.

Britons, you stay too long.

Quickly aboard bestow you,

And with a merry gale

10 Swell your stretched sail,

With vows as strong,

As the winds that blow you.

hinds a generalised term of abuse 
Your course securely steer,

West and by south forth keep,

15 Rocks, lee-shores, nor shoals,

When Aeolus $^{\dagger}$ scowls,

You need not fear,

So absolute the deep.

And cheerfully at sea,

20 Success you still entice,

To get the pearl and gold,

And ours to hold,

Virginia,

Earth's only paradise.

25 Where nature hath in store,

Fowl, venison, and fish,

And the fruitfullest soil,

Without your toil,

Three harvests more,

30 All greater than you wish.

And the ambitious vine

Crowns with his purple mass,

The cedar reaching high

To kiss the sky,

35 The cypress, pine

And useful sassafras. ${ }^{\dagger}$

To whose the golden age

Still nature's laws doth give,

No other cares that tend,

40 But them to defend

From winter's age,

That long there doth not live. 
When as the luscious smell

Of that delicious land,

45 Above the seas that flows,

The clear wind throws,

Your hearts to swell

Approaching the dear strand.

In kenning* of the shore

seeing

50 Thanks to God first given,

$O$ you the happiest men,

Be frolic* then,

joyous

Let cannons roar,

Frighting the wide heaven.

55 And in regions far

Such heroes bring ye forth,

As those from whom we came,

And plant our name,

Under that star

60 Not known unto our north.

And as there plenty grows

Of laurel everywhere,

Apollo's ${ }^{\dagger}$ sacred tree,

You it may see,

65 A poet's brows

To crown, that may sing there.

Thy voyages attend.

Industrious Hakluyt, ${ }^{\dagger}$

Whose reading shall enflame

70 Men to seek fame,

And much commend

To aftertimes thy wit.

1605-6

Apollo refers to Apollo as patron of poets; the laurel, which was sacred to Apollo, was used in antiquity for the crowns of poets Hakluyt Richard Hakluyt (here pronounced as three syllables) was the great Elizabethan chronicler of the discoveries; he described the voyages of explorers such as the Cabots, Drake, Frobisher and Ralegh 